\title{
The Parallel Roads of Glen Roy, Scotland: geoconservation history and challenges
}

Vanessa Brazier ${ }^{a *}$, John E. Gordon ${ }^{b}$, Martin Faulkner ${ }^{\mathrm{c}}$, Derrick Warner ${ }^{\mathrm{d}}$, Keith Hoole ${ }^{\mathrm{e}}$, Jim Blair

${ }^{a}$ Scottish Natural Heritage, Battleby, Redgorton, Perth PH1 3EW, UK

${ }^{b}$ School of Geography \& Geosciences, University of St Andrews, St Andrews KY16 9AL, UK

${ }^{c}$ Scottish Natural Heritage, Silvan House, 231 Corstorphine Road, Edinburgh, EH12 7AT, UK

${ }^{d}$ Scottish Natural Heritage, Torlundy, Fort William PH33 6SW, UK

${ }^{e}$ Lochaber Geopark Association, 55a High Street, Fort William PH33 6DH, UK.

* Corresponding author.

E-mail address: Vanessa.Kirkbride@snh.gov.uk

\begin{abstract}
Glen Roy is a classic geosite for ice-dammed lake shorelines, the Parallel Roads, and associated features formed during the Loch Lomond (Younger Dryas) Stade (12.9-11.7ka). The area played a key part in the development of the glacial theory in the early 19 th century and continues today to have outstanding scientific value for understanding the processes and timing of events at the end of the last glaciation. Glen Roy has also been longappreciated as an awe-inspiring visitor attraction, and is now a flagship site for geotourism within Lochaber Geopark. Statutory geoconservation in Glen Roy, beginning in the second half of the 20th century, was founded on the exceptional scientific value of the area. The history and practice of geoconservation in Glen Roy illustrate the contested values of geoheritage and the evolving approaches adopted. Important lessons include the need for open dialogue and partnership working among the local community, land owners and managers, the statutory conservation agency (Scottish Natural Heritage), Lochaber Geopark and the scientific community.
\end{abstract}

Keywords: Glacial lake shorelines; Geoheritage; Geoconservation; Geotourism; Glen Roy National Nature Reserve; Lochaber Geopark

" far the most remarkable area I ever examined.... I can assure you Glen Roy has astonished me"

(Charles Darwin writing to Charles Lyell after his visit to Glen Roy in 1838; Darwin, 1887, p. 293).

\section{Introduction}

The Parallel Roads of Glen Roy, and the neighbouring Glen Spean and Glen Gloy, together form one of the most famous geomorphological landscapes in Britain (Fig. 1). Already by the mid-19th century this 'remarkable area' in Lochaber was a magnet for the curious traveller, tourist and professional scientist, caught up in the enthusiasm for exploration, discovery, understanding and explanation of the natural world. This period marked a radical change in valuing the physical landscape as a source of both wonder and 
evidence of how the world works, rather than something to be explained through a tradition of colourful myths and legends (Gordon and Baker, 2016). It also coincided with the development of the glacial theory following the visit of Louis Agassiz to Scotland in 1840, when he recognised that the Parallel Roads were similar to the shorelines of ice-dammed lakes in the Alps (Gordon, 1995). Today, the landforms and deposits of Glen Roy and adjacent areas continue to have a particular relevance for modern research in Quaternary science relating to the processes and timing of landscape evolution and climate change during the Loch Lomond (Younger Dryas) Stade (12.9-11.7ka), as demonstrated by the papers in this special issue.

The history of conservation of these landmark landforms (Fig. 2) has mirrored the development of geoconservation nationally and globally, leading towards greater emphasis today on community-led initiatives and involvement than in the past (Burek and Prosser, 2008a; Gray, 2013). Conservation management of the Glen Roy landforms now involves an ongoing partnership with the people who live and work in the area to protect and retain the key areas of the designated Site of Special Scientific Interest (SSSI) in favourable condition (i.e. ensuring the visual and physical integrity of the key features and their accessibility). Here in Lochaber, and in the North West Highlands and Shetland, local people have driven the movement for recognition of their geoheritage through European and UNESCO Global Geopark status, part of a global trend in community-led geoconservation in the last 20 years (McKeever et al., 2010; Larwood et al., 2013). This paper examines the history and practice of geoconservation in Glen Roy and the surrounding area, how they have reflected changes in the values placed on this special landscape, and the lessons to be learned.

\section{Geoheritage and geoconservation: the changing context for valuing Glen Roy}

\subsection{The evolving statutory framework for geoconservation}

Geoheritage comprises those features of geodiversity that have intrinsic, scientific, educational, cultural, aesthetic or ecological value (Crofts and Gordon, 2015). Geoconservation is the practice of conserving, enhancing and promoting awareness of these features (Prosser, 2013a). It has progressed over time, broadly following the development of nature conservation, from an early and largely exclusive site protection approach based on scientific value to latterly a broader approach that recognises benefits for society and more closely reflects the links between people and nature (Burek and Prosser, 2008a; Gordon and Barron, 2012; Gordon et al., 2012; Gray, 2013; Prosser et al., 2013; Crofts and Gordon, 2015). During the 19th and early 20th centuries the recognition of scientific value as a basis to "preserve" key geological sites was ad hoc and often reactive to some threat, and done without any wider systematic evaluation of a site's relative significance in Britain or elsewhere. Examples in Scotland included initiatives to protect Salisbury Crags and Agassiz Rock in Edinburgh and Fossil Grove in Glasgow (Thomas and Warren, 2008), as well as a survey of vulnerable erratic boulders (Milne Home, 1872). However, the impetus to protect individual sites was limited because of private land ownership and an absence of supporting legislation (Thomas and Warren, 2008). Across Britain during the 19th and early 20th centuries the growing interest in, and concern about, specific places of geological and landscape interest was largely championed by geological societies and the National Trust (Burek, 2008), whereas at that time in North America and Europe the National Park movement offered greater opportunities to protect geological sites (Erikstad, 2008).

It has been argued that the stage when geoconservation can truly begin is when a country systematically assesses its geoheritage (Burek and Prosser, 2008b). In Great Britain, the move towards a more organised approach to selecting sites for conservation began after World War 2 with the passing of the National Parks and Access to the Countryside Act (1949) and the formation of the Nature Conservancy (NC). The Act provided 


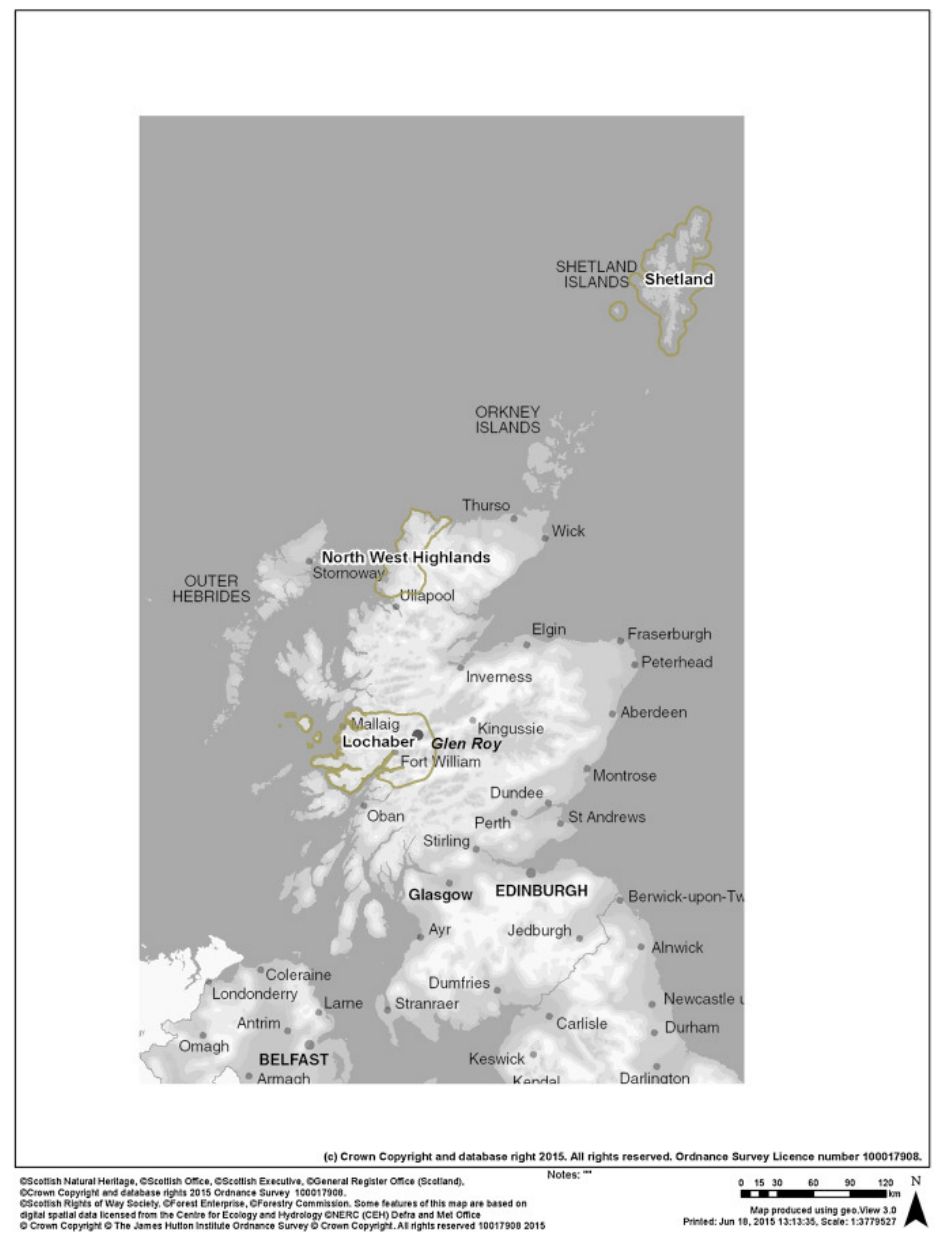

Fig. 1. Location of Glen Roy in Lochaber Geopark, Scotland. The locations of Geopark Shetland and North West Highlands Geopark are also shown.
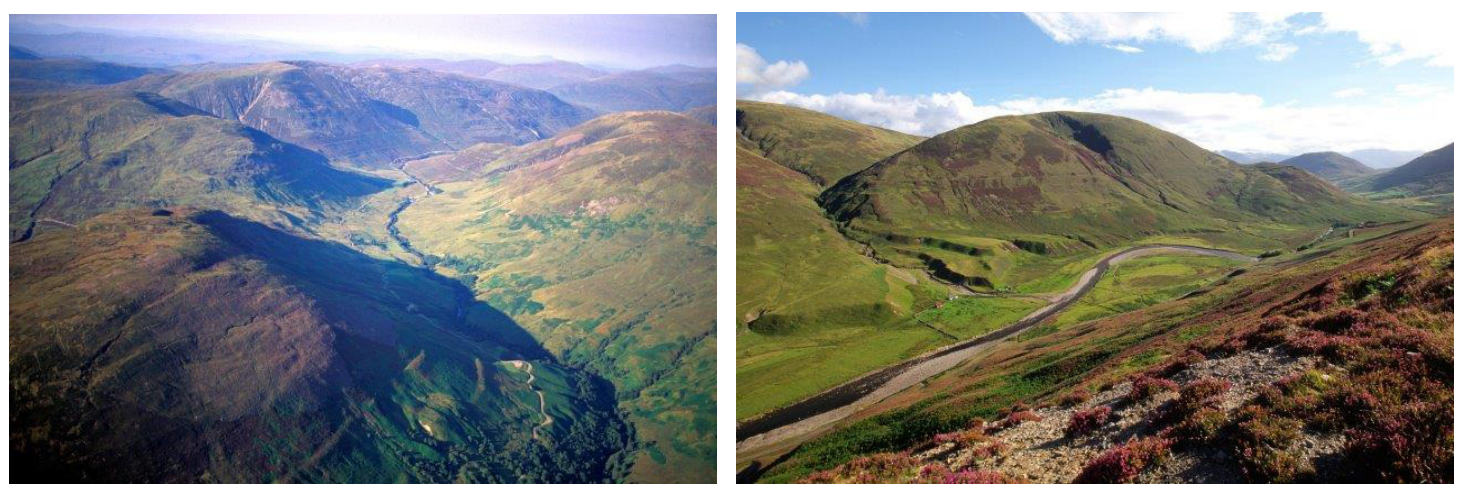

Fig. 2. (a). Aerial view of Glen Roy and the Parallel Roads (Photo () P\&A MacDonald/SNH); (b). Dissected alluvial fan at Brunachan forms part of the wider assemblage of landforms in Glen Roy (Photo @ L. Gill/SNH).

the legislative framework enabling the NC to designate Nature Reserves (NRs) ${ }^{1}$ where conservation and scientific research were the primary objectives. The NC also had a duty to inform local planning authorities of areas of land of special scientific interest (SSSIs) 
(Scottish Natural Heritage, 2011; Prosser, 2013b). Under the Act, NRs were considered tobe of greater importance and to provide a higher level of protection than SSSIs. Town and Country Planning legislation required planning authorities to consult the NC about development applications within designated SSSIs. However, it did not cover agriculture or forestry development. In the case of Glen Roy, the absence of any planning overview for sites targeted for afforestation galvanised conservation action in the 1950s onwards. Geoconservation was acknowledged through the employment of geologists within the NC and its successor body in 1973, the Nature Conservancy Council (NCC). These officials, notably William Macfadyen, were supported by eminent representatives from the geological societies, academics and the British Geological Survey who served on an independent advisory body, the Geological Conservation Council (GCC) between 1957 and c.1970 (Prosser, 2012). The Council's purpose was 'to take any action which may be desirable to conserve sites in Great Britain which are of scientific importance to geologists, either alone or in collaboration with the Nature Conservancy or other bodies, and to advise the Nature Conservancy on relevant geological matters'. The role of the GCC should not be underestimated, as internal NC memos from the 1950s and 1960s show that this body provided strong scientific support to secure the future of Glen Roy and other notable geosites.

The 1949 Act was superseded by the Wildlife and Countryside Act (1981), which introduced substantial changes to strengthen the conservation management of SSSIs. Significantly, it transferred responsibility to the landowner to notify the NCC of listed actions that could damage the conservation interests of an SSSI on their land. The 1981 Act brought improvements, but it did not address institutional barriers between government bodies responsible for conservation, agriculture and forestry (Mackay, 1995). All SSSIs in Scotland notified under the 1981 Act continue under the Nature Conservation (Scotland) Act 2004, which aimed to deliver better working partnerships between the devolved conservation agency, Scottish Natural Heritage (SNH), and the owners and occupiers of SSSIs. While other areas of nature conservation have been strengthened by European legislation, geoconservation has not.

\subsection{Changing values of geosites and local involvement in geoconservation}

In the UK, geosites have been assessed in terms of their value for science and education (Ellis, 2008, 2011; Prosser and Larwood, 2008). Outside the UK, other parameters have also been used to measure geoconservation value, including cultural symbolism, intrinsic and scenic value, aesthetic value, social and economic value, potential for tourism, and ecological value (Sharples, 2002; Carcavilla et al., 2009; dos Reis and Henriques, 2009; Reynard, 2009; Henriques et al., 2011; Tronkov and Sinnyovsky, 2012; Brilha, 2016). One of the more flexible approaches to evaluating landforms has been developed in Tasmania, where whole landform assemblages are recognised for their combined interest, with the inter-relationships of all landforms adding cumulative value, and as an intrinsic part of wilderness value (Sharples, 2003; Houshold and Sharples, 2008).

More recently, a broader approach now recognises the wider values of geodiversity and geoconservation for science and society, in addition to the core scientific and educational values explicit in the conservation of geosites (Henriques et al., 2011; Prosser et al., 2011, 2013; Gordon et al., 2012). This approach addresses the links between geodiversity, landscape and biodiversity conservation, and it highlights the role of geodiversity in supporting and regulating a wide range of activities and processes related to economic development, sustainable management of land and water, climate change adaptation, historical and cultural heritage, people's health and well-being, geotourism and the delivery of socio-economic benefits for local communities. Therefore as well as scientific and educational values, there is growing emphasis on the intrinsic, cultural, aesthetic and 
ecological values of geodiversity and its contribution to a range of ecosystem services (services provided by the natural environment that benefit people) (Stace and Larwood, 2006; Gordon and Barron, 2012, 2013; Gray, 2013; Gray et al., 2013; Crofts and Gordon, 2015). This is also recognised in the publication by the voluntary sector, with government endorsement, of Scotland's Geodiversity Charter (Scottish Geodiversity Forum, 2013) and the Geodiversity Charter for England (English Geodiversity Forum, 2014).

At a local level, these trends are evident in the development of networks of local geoconservation sites (Whiteley and Browne, 2013) and the engagement of local geological societies and trusts in their management and interpretation, as well as in the production of Local Geodiversity Action Plans (Burek, 2008, 2012). At the same time, the global growth of both the Geopark movement and geotourism (Dowling, 2011) has allowed a more inclusive focus on 'nature and people' rather than an exclusive scientific approach, and provided additional impetus for practical geoconservation (Wang et al., 2015). The aims of Geoparks include the conservation of geodiversity and geoheritage and promotion of sustainable economic and social development linked to geotourism and wise use of geoheritage resources in partnership with local communities (McKeever et al., 2010; UNESCO, 2016). The Geoparks movement generally has energised the engagement of local communities, part of a process of connecting geosites with people and communities, so that if people appreciate and value their landscape, they will help to protect it.

Concomitant with these recent developments and particularly with the growth of Geoparks, the role of effective interpretation has become crucial in sustaining and fostering wider appreciation of the value of geoheritage and the importance of geoconservation (Hose, $2000,2006,2012)$. Consequently, there has been a move away from didactic approaches to geoheritage interpretation and communication and a return to elements of good storytelling, to reconnect people with the landscape they see (Strauss, 2007; Gordon, 2012; Stewart and Nield, 2013; Gordon and Baker, 2016), and with different levels of interpretation for different audiences (Wang et al., 2015).

\section{Changing values attached to Glen Roy and the surrounding area}

Today we know little of what people from the past living in Glen Roy thought about the landscape in which they lived. In the 18th century, upper Glen Roy was used as a 'highway' for moving cattle and military personnel and supplies through from upper Strath Spey (Inglis, 1934), with single-span bridges near Braeroy surviving today from these times (Miers, 2008; Canmore ID 108783). Glen Roy itself was once populous, evident from the ruins found throughout the glen, as elsewhere in Lochaber. We do not know what notice or value local people really gave to the Parallel Roads, or to stories of them being the roads to Inverlochy Castle or Fingal's hunting roads. The retelling of these myths may be a romanticised Victorian embellishment of the original tales. What we do know is that Highland customs and society changed fundamentally following the suppression of the 18th century Jacobite rebellions, and as a consequence of rural depopulation throughout the 19th century to the growing industrial heartland of Scotland and emigration to the colonies. People moved away from the land, and for many the connection with the land was lost. However, depopulation was not always wholesale, and indeed Glen Roy itself retained one of the last Gaelicspeaking communities in mainland Scotland into the mid-20th century (Miers, 2008).

The artists and poets of the Romantic period in the late 18th and early 19th centuries changed people's perceptions of wild landscapes, from being detestable to being worthy of admiration and celebration. Scenery that inspired a sense of awe and wonder became popular, and it became fashionable to visit what later became geoconservation sites like the Falls of Clyde, Staffa and Fingal's Cave, Loch Coruisk on Skye and Glencoe (Hose, 2010; Gordon, 2012; Gordon and Baker, 2016). With increased incomes from industrial and 
agricultural development and improvements in transport, travel and exploration of scenic landscapes became a mass activity. Travel journals, literature, art and science all generated new interest in the Scottish Highlands, and in particular places associated with dramatic scenery or curious natural phenomena (Hose, 2010; Gordon and Baker, 2016). By the late 18th and early 19th centuries, the Parallel Roads were already a 'tourist' attraction and were being visited by early travellers and gentry such as the Grants of Rothiemurchus (Grant, 1988). Their appeal and mysterious origins were promoted in many popular travel accounts and contemporary guidebooks. The 19th century scientific debate about the origins of the Parallel Roads marked an important change in the way this part of Lochaber was perceived and valued, a change that would eventually lead to conservation designations and conservation management in the latter half of the 20th century (Table 1).

\section{Table 1}

Some key events and dates in the interpretation, evaluation and geoconservation history of Glen Roy.

\begin{tabular}{|c|c|}
\hline Date & Event \\
\hline 1771 & $\begin{array}{l}\text { Thomas Pennant noted that the Parallel Roads were already a 'celebrated' } \\
\text { landmark and the local belief that they had been constructed to facilitate } \\
\text { hunting. }\end{array}$ \\
\hline 1805 & $\begin{array}{l}\text { George Bellas Greenough interpreted the Parallel Roads as the shorelines of } \\
\text { a former lake. }\end{array}$ \\
\hline $1815-1817$ & $\begin{array}{l}\text { John Macculloch and Thomas Dick Lauder independently studied the } \\
\text { Parallel Roads and interpreted them as (non-glacial) lake shorelines. }\end{array}$ \\
\hline 1838 & Charles Darwin proposed that the Parallel Roads were marine shorelines. \\
\hline 1840 & $\begin{array}{l}\text { Louis Agassiz interpreted the Parallel Roads as the shorelines of ice- } \\
\text { dammed lakes and announced the former presence of glaciers in Scotland. }\end{array}$ \\
\hline 1863 & $\begin{array}{l}\text { Thomas Jamieson published the first detailed account of the formation of the } \\
\text { Parallel Roads as glacial lake shorelines. }\end{array}$ \\
\hline 1948 & $\begin{array}{l}\text { Professor J.G.C. Anderson compiled a list of recommendations for } \\
\text { geological nature reserves in Scotland that included Glen Roy. }\end{array}$ \\
\hline 1949 & $\begin{array}{l}\text { The National Parks and Access to the Countryside Act (1949) included } \\
\text { provisions to form the Nature Conservancy and the first legislation for the } \\
\text { conservation of protected areas (Nature Reserves and Sites of Special } \\
\text { Scientific Interest (SSSIs)) in Great Britain. }\end{array}$ \\
\hline 1954 & $\begin{array}{l}\text { Glen Roy and parts of Glen Gloy and Glen Spean were first designated as } \\
\text { an SSSI. }\end{array}$ \\
\hline $1950 s-1960 s$ & $\begin{array}{l}\text { The Parallel Roads were included in the UK's ambitious post-war timber } \\
\text { planting programme. }\end{array}$ \\
\hline 1967 & $\begin{array}{l}\text { The Geological Conservation Committee met in Edinburgh and expressed } \\
\text { frustration at the delay in declaring Glen Roy as a Nature Reserve. }\end{array}$ \\
\hline 1970 & Glen Roy was declared as a National Nature Reserve (NNR). \\
\hline 1973 & $\begin{array}{l}\text { The Nature Conservancy Council (NCC) was formed to replace the Nature } \\
\text { Conservancy. }\end{array}$ \\
\hline 1977 & The Geological Conservation Review (GCR) began. \\
\hline 1977 & $\begin{array}{l}\text { An interpretation booklet on Glen Roy NNR by Brian Sissons was published } \\
\text { by the NCC. }\end{array}$ \\
\hline $1970 s-1980 s$ & $\begin{array}{l}\text { Brian Sissons published a series of papers detailing the sequence of events } \\
\text { in the formation of the Parallel Roads and related landforms. Sissons' } \\
\text { studies formed the basis for the GCR site assessment of Glen Roy. }\end{array}$ \\
\hline 1981 & $\begin{array}{l}\text { The Wildlife and Countryside Act (1981) strengthened the protection of } \\
\text { SSSIs. }\end{array}$ \\
\hline 1986 & The extended Parallel Roads of Lochaber SSSI was renotified under the \\
\hline
\end{tabular}


Wildlife and Countryside Act (1981).

A Quaternary Research Association Field Meeting was held in Glen Roy. The Natural Heritage (Scotland) Act 1991 included provisions to establish Scottish Natural Heritage (SNH) (1992), with devolved responsibility for nature conservation in Scotland.

1993 The Quaternary of Scotland Geological Conservation Review (GCR) volume was published. The Fluvial Geomorphology GCR volume was published. The Nature Conservation (Scotland) Act 2004 required SNH to review all SSSIs in Scotland and to rationalise the lists of Operations Requiring Consent where there was overlap between the remits of $\mathrm{SNH}$ and other public bodies.

$2004 \quad$ Lochaber Geopark Association was founded. Fashioned by Geology' series.

2007 Lochaber Geopark became a member of the European Geoparks Network (EGN).

2008 A Quaternary Research Association Field Meeting was held in Glen Roy. The Geological Society of London, History of Geology Group Filed Trip: The Parallel Roads of Glen Roy: in the footsteps of Charles Darwin.

$2010 \quad$ Under the Nature Conservation (Scotland) Act 2004, the list of Operations Requiring Consent for the Parallel Roads of Lochaber SSSI was reviewed, a new SSSI management plan produced, and the legal citation updated to include the importance of the site for the history of science.

2011 Lochaber Geopark defaulted from the EGN but continued as a national geopark.

2012 EU COST Action Field Trip for the INTIMATE (Integrating Ice Core, Marine and Terrestrial Archives) Group visited Glen Roy.

2013 The Scottish Government provided funding for 3 years to support the development of Scotland's 3 Geoparks.

2014 Glen Roy was included in the Geological Society of London's list of '100 Great Sites' in Britain.

$2015 \quad$ Lochaber Geopark opened a visitor centre in Fort William and Darwin's Rest Geopark hub in Roy Bridge at the entrance to Glen Roy.

2015 Glen Roy was included in the Quaternary Research Association's list of 'Top 50 Quaternary Sites' in Britain.

2015 The NNR status of Glen Roy was reviewed by SNH following a change in NNR principles and criteria. A proposal to de-declare the NNR, although it would still retain its protected status as an SSSI, was deferred after representations from Lochaber Geopark and the scientific community. Lochaber Geopark re-applied for European Geopark/UNESCO Global Geopark status.

2016 Publication of a Special Issue of the Proceedings of the Geologists' Association on Glen Roy.

\subsection{Scientific discovery, debate and current value}

The Parallel Roads were probably first brought to the attention of the wider world through the travel journal of Thomas Pennant (1771). Although prevented from visiting Glen Roy by bad weather, he recorded that the Parallel Roads were already a 'celebrated' landmark. In The Statistical Account of Scotland, Ross (1796) noted that they were locally believed to be hunting roads constructed for the kings of Scotland or by the Gaelic mythical hero, Fingal. During the first half of the 19th century, the Roads attracted considerable scientific attention at a time when the modern science of geology was rapidly developing 
following the publication of James Hutton's Theory of the Earth (Hutton, 1788) and the formation of the Geological Society of London in 1807. Explanation of their formation was one of the great scientific challenges of the time and they played an important part in the development of the understanding of landscape evolution and scientific methodology in geology (Rudwick, 1974, 2009).

George Bellas Greenough, the first president of the Geological Society, was probably the first geologist to visit the Parallel Roads during his tour of Scotland in 1805, proposing in his journal that they were the shorelines of a former lake (Rudwick, 1962). Later, during the course of more detailed field investigations, John Macculloch (1817) and Thomas Dick Lauder (1823) concurred with this explanation, although the origin of the barrier that dammed the lakes remained problematic (Rudwick, 2016).

Charles Darwin and Charles Lyell were influential proponents of a marine origin for the Parallel Roads. Darwin, influenced by his voyage to South America, was deeply impressed by the uplift of the Chilean coastline by recent earthquakes and proposed that the sea had similarly penetrated and then retreated from Glen Roy and adjacent glens (Darwin, 1839). Such an interpretation, moreover, supported his ideas on crustal elevation and subsidence which formed an important element in explaining the species distributions of island faunas (Rudwick, 1974). It was only later in 1861 that he recanted and accepted that the roads represented the shores of a former glacial lake. "My paper was one long gigantic blunder from beginning to end", he wrote to Lyell in 1861 (Darwin and Seward, 1903, p. 188).

The Swiss geologist, Louis Agassiz, provided the key to unlock the mystery of the lake dam (Gordon, 1995). Following a presentation of his ideas on the glacial theory at a meeting of the British Association in Glasgow in 1840, he toured the Western Highlands, accompanied by William Buckland, Professor of Geology and Mineralogy at the University of Oxford. They found widespread traces of former glaciers, particularly in the Glen Roy-Glen Spean area, and Agassiz recognised the Parallel Roads to be the shorelines of former icedammed lakes, similar to modern features he had observed near Chamonix (Maclaren, 1840; Agasiz, 1841, 1842). Agassiz's discovery of the former existence of glaciers in Scotland was announced to the wider public in The Scotsman newspaper on 7 October 1840 (Maclaren, 1840). In providing compelling field evidence to substantiate Agassiz' Ice Age theory, Glen Roy played a significant part in one of the major advances in geological science in the 19th century.

Nevertheless, Agassiz' interpretation of the Parallel Roads as glacial lake shorelines remained contested until Thomas Jamieson worked out the detailed story of their formation (Jamieson, 1863, 1892). The sequence of events proposed by Jamieson has since been elaborated in more modern studies, notably by Brian Sissons (1978, 1979a, 1979b, 1979c, 1981a, 1981b; Sissons and Cornish, 1982a, 1982b, 1983). Sisson's work demonstrated the importance of the wider landform assemblage extending from Loch Laggan and Loch Treig to near Fort William, and north from Glen Spean to the Great Glen (Fig. 3). As well as lake shorelines in Glen Roy, Glen Gloy and Glen Spean, the landforms include moraines, deltas, alluvial fans, meltwater gorges, lake deposits, river terraces and kettle-holes (Fig. 2). These features illustrate geomorphological processes during successive stages of the development of the glacial lakes and their subsequent catastrophic drainage. Several landslides in Glen Roy and Glen Gloy have also been linked to slope instability associated with the sudden draining of the lakes and the rapid unloading of the ground, while detailed levelling of the shorelines has demonstrated differential glacio-isostatic uplift and dislocation of crustal blocks (Sissons and Cornish, 1982a, 1982b). More recent studies have added to the scientific understanding and value of the area (Fabel et al., 2010; Macleod et al., 2011; Palmer et al., 2010, 2012; Ballantyne, 2012; Bendle et al., 2015; Boston and Lukas, 2016; Devine and Palmer, 2016; Sissons, 2016a, 2016b), with key issues also discussed during and following Quaternary Research Association (QRA) Field Meetings in 1989 and 2008 
(Peacock and Cornish, 1989; Palmer et al., 2008; Peacock, 2009). Today, the Parallel Roads and their associated assemblage of landforms and deposits represent not only an internationally famous landform landmark, but also a key asset for interpreting the pattern, processes and timing of landscape and environmental changes during the last glacialinterglacial transition. Wider accolades include recognition in the Quaternary Research Association's list of 'Top 50 Quaternary Sites' in Britain (https://www.qra.org.uk/top-50quaternary-websites/, accessed 10 October 2016) and the Geological Society of London's list of '100 Great Sites' in Britain (https://www.geolsoc.org.uk/100geosites, accessed 10 October 2016).

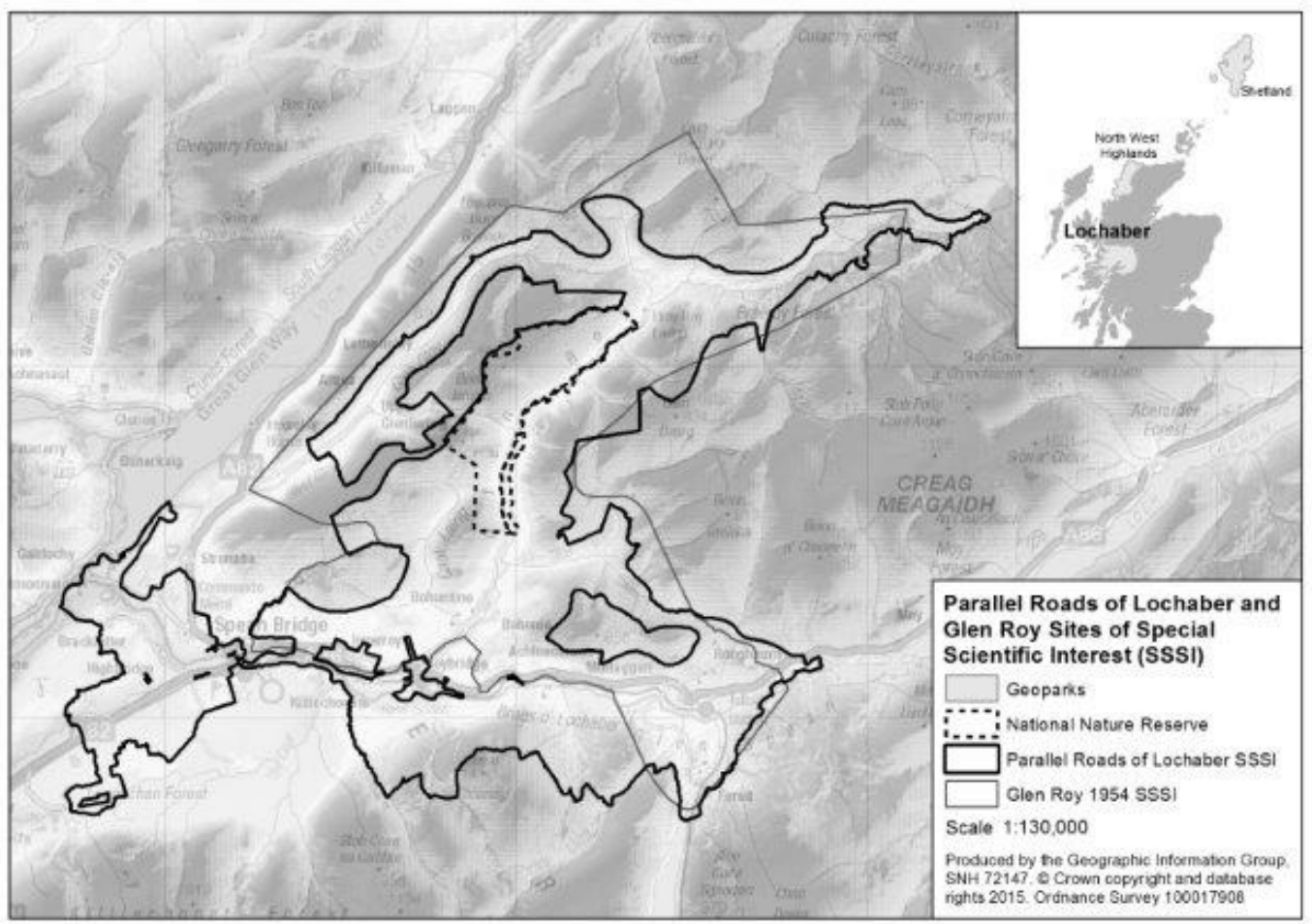

Fig. 3. Changes in conservation designations showing the original Glen Roy SSSI designated in 1954 under the National Parks and Access to the Countryside Act (1949), the Glen Roy NNR declared in 1970 and the Parallel Roads of Lochaber SSSI designated in 1986 under the Wildlife and Countryside Act (1981).

\subsection{Geoconservation in practice: the role of the statutory bodies}

The scientific discoveries in Glen Roy added greatly to the perceived value of this landscape by the scientific community. However, recognising the scientific significance of a place has not easily translated into effective protection of the landscape. Glen Roy was first included on lists of potential geoconservation sites in the late-1940s, but it has proved at times difficult first to gain, and even more recently to retain, nature reserve status. The Glen Roy area is currently protected as an SSSI, and part of the glen is declared a National Nature Reserve (NNR). The effectiveness of these two types of site protection has changed over time, with nature reserves initially affording more robust conservation protection than SSSIs. However, that position has now more or less reversed, with SSSIs offering the substantive element of protection, while NNR status serves as an accolade and with a focus on management for nature and for people to enjoy nature, as discussed below. 
In 1948, Professor J.G.C. Anderson of the Geological Survey of Scotland prepared a list of 60 sites for Scotland, following the list of recommendations of geological reserves for England and Wales compiled by the geological sub-committee of the of Nature Reserves Investigation Committee established by the Society for the Promotion of Nature Reserves (Gordon, 1994). The list included Glen Roy and provided the starting point for geosite protection in Scotland undertaken by the NC during the years following its formation in 1949. Anderson's list of 60 sites was widely circulated for comment in December 1950 and January 1951. By 1953, the list of recommendations arising from these consultations had expanded to 96 sites, while the Geological Survey of Scotland had produced a list with a further 65 sites. In 1954, when Glen Roy and parts of Glen Gloy and Glen Spean were first designated as an SSSI (Fig. 3), the officially recommended list of geosites for Scotland contained 169 sites. Despite a rolling programme of updates, there were many deficiencies in the selection of earth science SSSIs, and in 1977 the Geological Conservation Review (GCR) was set up by the NCC to provide a comprehensive and systematic assessment of key sites representing the scientific interests of the geology and geomorphology of Great Britain (Ellis, 2008, 2011). By 1990, almost 3000 GCR sites had been selected, and most have been wholly or partially designated as SSSIs. The scientific importance of Glen Roy was confirmed in the Quaternary of Scotland GCR volume (Gordon, 1993). In addition, the fluvial landforms in Glen Roy, including alluvial fans, deltas and river terraces, also qualified in their own right for inclusion in the Fluvial Geomorphology of Scotland block of the GCR (Gordon and McEwen, 1997).

Inclusion on Anderson's list of geosites was the start of a protracted process to protect Glen Roy over a period of nearly two decades from the early 1950s and involved fundamental disagreement between two government bodies over the tenure, afforestation and conservation of large areas of Glen Roy. At the time, the Forestry Commission (FC) was launching an ambitious post-war, UK-wide timber planting programme (Coppock 1960; Mather, 1978). It began buying upland estates across Scotland and assessed Glen Roy and the surrounding area as suitable for afforestation.

In 1953 the FC announced its intention to buy the Glen Spean estate, despite advice given by the NC of the international importance of the Parallel Roads, and plans were developed for blanket plantation forestry for the slopes of Glen Roy. The conservation concerns were that the plantations would conceal the landforms and also permanently damage parts of them through the construction of access tracks and extensive drainage. In 1954 the Scottish Committee of the NC agreed that Glen Roy should be designated as a Nature Reserve, including most of the glen (the proposed boundary would have been similar to the 1954 SSSI boundary), and requested that the FC should not plant any trees within this proposed reserve. Negotiations over land use continued, but by 1955 the FC informed the $\mathrm{NC}$ that it could not guarantee to refrain from tree planting within the area. While the debate about forestry continued, the NC designated the Parallel Roads of Glen Roy as an SSSI in February 1954 under the 1949 Act, and notified the county planning officer, but not the land owners (not a requirement at this time). However, progress stalled on the notification of a nature reserve with its then greater powers of protection, which would have effectively blocked afforestation. This is perhaps not surprising in the prevailing political climate as it would have required ministerial consent for the purchase of a large area of land with crofting interests to be set aside for conservation.

Antagonism between the two government-funded organisations (Mackay, 1995) reached a head in 1956, when the FC acquired Glen Spean estate and announced that it intended planting to within 50 feet of the lowest ice-dammed lake shoreline. The FC also further investigated the potential for planting areas of Inverroy and Braeroy estates within Glen Roy. Intervention from eminent geoscientists and bodies such as the GCC continued throughout this time. For example, in January 1957, the Geological Society of London and the Royal Society of Edinburgh submitted letters to the Secretary of State for Scotland requesting 
ministerial intervention, making the case for opposing all tree planting in Glen Roy in the area of the proposed nature reserve. Interventions such as these highlight the inadequate protection that the SSSI designation under the 1949 Act afforded the conservation interests of Glen Roy in relation to forestry. Ministerial concerns focused on rural depopulation, so that by November 1957 the Crofters Commission was involved in discussions about the forestry proposals. In 1958, agreement was reached for some areas of plantation within the wider area of Glen Roy, which can be seen today. Also in 1958, the FC proposed to plant trees on the Beinn laruinn area of Glen Roy, but agreed to defer a decision until 1968. In response to this temporary pause in tree planting, a meeting of the GCC was held in December 1967. This included eminent geoscientists who were determined to secure protection of Glen Roy and the removal of the threat of blanket afforestation (Table 2). The minutes of the meeting reveal frustration at the continued delay in declaring a nature reserve, some 14 years after the first designation of the SSSI. The most significant actions agreed at the meeting were to increase the amount of research in Glen Roy and to publicise the evidence for the icedammed lakes and the scientific importance of the glen.

\section{Table 2}

Participants at the Geological Conservation Committee meeting on 5 December 1967, at the Nature Conservancy offices in Hope Terrace, Edinburgh.

\begin{tabular}{|c|c|c|}
\hline Name & & Affiliation \\
\hline Dr M.E.D Poore & Chairman & Nature Conservancy \\
\hline Professor J.G.C. Anderson & & University College Cardiff \\
\hline Professor G.Y. Craig & & University of Edinburgh \\
\hline Dr H.I. Drever & & University of St Andrews \\
\hline Professor T. Neville George & & University of Glasgow \\
\hline Professor D.L. Linton & & University of Birmingham \\
\hline Professor R.M. Shackleton & & University of Leeds \\
\hline Mr J.D.D. Smith & & Geological Survey and Museum, London \\
\hline Professor H.C. Versey & & University of Leeds \\
\hline & mivitees & \\
\hline Lord Arbuthnott & & Nature Conservancy \\
\hline Dr G.P. Black & & Nature Conservancy \\
\hline Dr W.J. Eggeling & & Nature Conservancy \\
\hline Miss N.J. Gordon & & Nature Conservancy \\
\hline Dr J.D. Peacock & & Institute of Geological Sciences \\
\hline Mr G. Scott Johnston & & Institute of Geological Sciences \\
\hline Dr J.B. Sissons & & University of Edinburgh \\
\hline Mr J.G. Roger & & Nature Conservancy \\
\hline Professor J. Wreford Watson & & University of Edinburgh \\
\hline
\end{tabular}

Public support at the time against afforestation is reflected in an open letter published in The Field, written by a local Roy Bridge resident who argued that it should be a national decision to stop the forestry proposals in Glen Roy (Kennedy (1968). Kennedy explained that forestry would bring little local employment, but would destroy the famous Parallel Roads.

In 1969, the NC submitted a proposal to the Treasury to purchase part of Glen Roy from the FC, and at the time this was seen as a way to settle the dispute and secure the conservation of the Parallel Roads and associated landforms. In July 1970, the 2887 acres $\left(11.7 \mathrm{~km}^{2}\right)$ of land purchased by the NC was declared a National Nature Reserve (NNR) for its internationally important geomorphological heritage, and tenanted grazing rights were 
transferred with the land ownership. The area finally declared an NNR, however, was much smaller than in the original proposal in the 1950s (Fig. 3). Subsequently in 1986, following the GCR site assessment, the SSSI was renotified as the Parallel Roads of Lochaber SSSI under the Wildlife and Countryside Act (1981), with a revised and extended boundary that recognised the wider assemblage of landforms and covering an extensive area of 14,496 ha $\left(145 \mathrm{~km}^{2}\right)$ (Fig. 3).

Practical statutory conservation has continued to evolve since the formation of $\mathrm{SNH}$ in 1992. Following the Nature Conservation (Scotland) Act 2004, reviews of all SSSIs resulted in new site management plans which set out conservation objectives. Supported by a geomorphological audit (Peacock, 1989), those for the Parallel Roads of Lochaber SSSI (which includes Glen Roy) are to:

1. maintain the physical integrity of the landform assemblages within the site by ensuring developments involving earth movements (such as housing developments, construction of tracks, infilling of quarries, or large-scale sand and gravel quarrying) are assessed carefully for their likely impacts and carried out sensitively; and

2. maintain or enhance the visibility and accessibility of the landforms and sediments by continuing positive grazing management of the site and by ensuring that developments, such as afforestation, felling and restructuring of forestry plantations, or woodland regeneration, are assessed carefully for their likely impacts and carried out sensitively.

There is a great variety of land uses and land ownership across the Parallel Roads of Lochaber SSSI, including forestry, rough grazing, sand and gravel quarrying, hydroelectric power generation, conservation and recreation interests, as well as a large number of private homes. The SSSI designation means that owners and occupiers have to apply to SNH for consent to carry out listed operations (Table 3), to Forestry Commission Scotland (FCS) for forestry developments, and to SEPA for licences under The Water Environment (Controlled Activities) (Scotland) Regulations 2011. Similarly other regulatory bodies have to consult $\mathrm{SNH}$ before approving proposals on SSSIs. In general, this means that there can be dialogue between $\mathrm{SNH}$ and the owner or occupier, and other regulatory bodies. This provides opportunities to explain the conservation objectives, and where necessary, modify activities to protect the landforms in the SSSI. There have been 50 such applications for consent for listed operations since 2003, with very few being turned down. However, the vast majority of cases are generated from the planning system (128 cases since 2003), and many have been planning applications for houses (Table 4).

\section{Table 3}

The Parallel Roads of Lochaber SSSI: list of operations requiring consent from SNH.

\begin{tabular}{ll}
\hline $\begin{array}{l}\text { Standard } \\
\text { number }\end{array}$ & $\begin{array}{l}\text { Operations requiring consent from SNH, unless covered by Planning } \\
\text { Consent }\end{array}$ \\
\hline 7 & $\begin{array}{l}\text { Dumping, spreading or discharge of any materials (except fertilisers, lime } \\
\text { and manure). }\end{array}$ \\
20 & $\begin{array}{l}\text { Extraction of minerals including sand and gravel, topsoil or sub-soil. } \\
\text { Construction, removal or destruction of tracks, walls, fences, hardstands, } \\
\text { banks, ditches, or other earthworks, or the laying, maintenance or removal }\end{array}$ \\
& $\begin{array}{l}\text { of pipelines and cables, above or below ground. } \\
\text { Modification of natural or man-made features. }\end{array}$ \\
\hline
\end{tabular}


Table 4

Types of conservation casework on the Parallel Roads of Lochaber SSSI, 2003-2015.

\begin{tabular}{lr}
\hline Conservation casework consultation type & $\begin{array}{r}\text { Number } \\
\text { of cases }\end{array}$ \\
\hline Development and Planning (mostly housing) & 128 \\
Requests for consent to carry out notifiable operations & 50 \\
within the SSSI & 35 \\
Forestry developments and plans & 26 \\
Infrastructure - utilities, water, waste, electricity, telecoms, & 23 \\
trunk roads, railway, core paths & 14 \\
General advice or information about the SSSI & \\
Agriculture and rural development & 12 \\
Owner/occupier advice (not relating to applications for & 11 \\
consent) & 8 \\
Environmental Protection Act and EIA & 3 \\
Controlled Activities Regulations (rivers) & 2 \\
Mineral workings & 1 \\
Species & \\
Other plans and strategies & \\
\hline
\end{tabular}

In general, there have been huge improvements in relations with landowners and land users, and the Nature Conservation Act (2004) review resulted in a reduction in the number of activities for which a landowner is required to obtain consent. In the case of the Parallel Roads of Lochaber SSSI, the number reduced from 9 to 4 activities (Table 3). The 'introduction of tree and woodland management' is no longer listed. However, all large forestry operations are assessed by the FCS, which consults SNH when the land is an SSSI. Indeed, changes within the forestry industry in recent decades to more natural forestry following the post-war afforestation expansion have created opportunities for conservation enhancement (Mather, 2001). In the last 10 years, consultations between the FCS and SNH over Long Term Forest Plans, Forest Design Plans and felling licence applications from commercial forestry operations within the SSSI (Table 4) have resulted in more open deciduous replanting, revealing previously obscured landforms, like the delta landforms near Loch Laggan in Glen Spean. These new approaches to forestry and woodland planning and management have wider conservation benefits for biodiversity, as well as providing opportunities to revisit the management of once blanket forest covered areas of the SSSI. Fostering good working relationships with all landowners and land managers, who manage both small and large areas of the SSSI, will continue to be the key to successful conservation of the SSSI by SNH.

Glen Roy NNR covers only a small area of the wider Parallel Roads of Lochaber SSSI (Fig. 3), including the iconic viewpoint in Glen Roy and a representative area of the Parallel Roads. The original need for nature reserve status was to protect the site more effectively than the initial SSSI legislation allowed. The management objectives for Glen Roy NNR have remained more or less the same since its declaration in 1970:

a. To protect the "Parallel Roads" and associated landforms found within the Reserve from damaging influences which would reduce their physical and visual integrity.

b. To maintain the biological habitats on the Reserve and where appropriate enhance their value providing this does not compromise the visual and physical integrity of the geomorphological features of interest. 
c. To encourage research, survey and monitoring appropriate to the Reserve.

d. To encourage local people and visitors to enjoy and appreciate the natural heritage on the Reserve.

e. To manage the property on the Reserve responsibly following best practice. These objectives are now covered by the site's SSSI status and provisions for managing the site.

In 2015, the NNR accolade was contested when the Board of SNH reviewed Scottish NNRs against a set of revised principles and criteria for NNR status (http://www.snh.gov.uk/docs/A1576100.pdf, accessed 10 October 2016) and proposed that Glen Roy, along with several other sites, should lose its NNR status (without any change in its SSSI status). The revised principles highlight a shift from an exclusive focus on management for research and preservation in the 1949 Act to include greater emphasis now on enabling enjoyment of nature by people. There are options for reserve management by a range of public, private, community and voluntary organisations and with the accolade managed by a partnership representing these organisations. This shift in emphasis in the objectives of NNRs, from 'protection without people' to 'promotion and enjoyment', is parallelled in England where Natural England (NE) manages about two thirds of England's NNRs, with the remainder managed by organisations approved by NE, for example, the National Trust, Forestry Commission, RSPB, Wildlife Trusts and local authorities. In the case of Glen Roy, and some other NNRs, it is argued that the conservation interests are already adequately protected by SSSI designation and that some NNRs, including Glen Roy NNR, are no longer a good fit for SNH's NNR programme, especially at a time of reduced public spending. There may be opportunities for the local community to be more involved in Glen Roy, through the Community Empowerment (Scotland) Act 2015 (http://www.gov.scot/Topics/People/engage/CommunityEmpowermentBillFAQs, accessed on 3 November 2016 ), with the site continuing to be managed in accordance with its SSSI status.

There are constraints that have limited the development of Glen Roy NNR in the past, including the steep ground away from the public road and most of the NNR being under crofting tenure. The main investment in the NNR was the car park, which provides an excellent viewpoint up the glen. This has been a good vantage point for interpretation, and currently hosts new interpretation boards owned, designed and installed by Lochaber Geopark (Fig. 4). Previous leaflets and booklets have also interpreted the origins of the landforms in Glen Roy, and how scientific understanding has progressed over the last 150+ years (Sissons, 1977; Peacock et al., 2004).
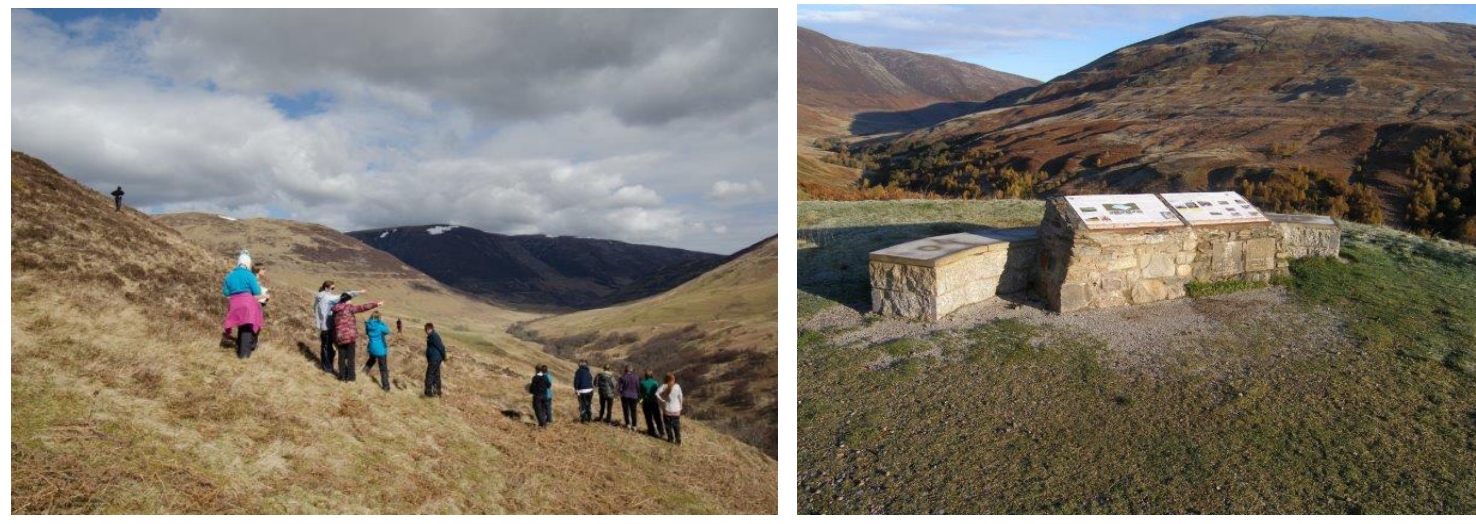

Fig. 4. (a) Students visit the $260 \mathrm{~m}$ shoreline above the viewpoint car park, looking northwards up Glen Roy, while on the Royal Holloway University of London MSC Quaternary Science Field Training Course (Photo (c) C. Francis). (b) Interpretation boards installed the viewpoint in Glen Roy by Lochaber Geopark in 2014 (Photo @ Jim Blair). 


\subsection{Geoconservation in practice: the voluntary sector}

Lochaber Geopark Association was founded in 2004, becoming a member of the European Geopark Network (EGN) and the Global Geopark Network (GGN) from 2007 until 2011, when it withdrew because of insufficient funding to meet minimum EGN membership requirements, but it still functions as a national geopark. Since its formation, Lochaber Geopark Association has been a community-based organisation, promoting geoconservation and enjoyment of Lochaber's spectacular scenery and geodiversity, with the support of volunteers, local businesses and partner organisations, including the John Muir Trust, The Association of Lochaber Community Councils, the Nevis Partnership, the Lochaber Chamber of Commerce, the British Geological Survey, the Forestry Commission, the National Trust for Scotland, VisitScotland and SNH. The Scottish Government provided funding over the period 2013-2015 to develop a sustainable business plan for the Geopark, as well as support for the other Scottish Geoparks in the North West Highlands and Shetland. This enabled Lochaber Geopark to apply for re-admission to the EGN/GGN in 2016, with a decision expected in 2017.

Lochaber Geopark Association currently employs 2 full-time staff in Fort William, and operates Darwin's Rest, a coffee shop and visitor centre in Roy Bridge at the entrance to Glen Roy, where there is a small display interpreting the Parallel Roads. The Association has an overall vision to ensure that Lochaber gains the maximum benefit from its rich geoheritage, including Glen Roy. It runs guided walks in Glen Roy, which offer a personalised view of the geodiversity and have proved popular and rewarding excursions for local people and visitors. The Geopark as a whole raises awareness and promotes appreciation of Lochaber's geoheritage, in particular working with the tourism industry based in and around Scotland's 'outdoor capital', Fort William. In 2014, the Geopark Association erected new interpretation boards at the main viewpoint in Glen Roy (Fig. 4) and featured Glen Roy as one of its 8 Lochaber Geotrails.

SNH's proposal that Glen Roy should lose its NNR accolade because it no longer fits with current NNR criteria was contested in a campaign led by Lochaber Geopark Association. In 2015 the Association wrote to the Scottish Government seeking explanation for the proposed de-declaration of Glen Roy NNR, which had been fought over so hard in the 1950 s and 1960s, giving voice to local concerns that this might be seen as diminishing the international value of the area and its prestige as a visitor attraction at a time when the Association were preparing to reapply for EGN/GGN status. In July 2015, the Geopark also set up an online petition to galvanise support for retaining Glen Roy NNR, gaining nearly 1500 signatures in a few weeks. The campaign was supported through submissions to SNH by the Quaternary Research Association (QRA) and the Royal Scottish Geographical Society (RSGS), as well as by local people and individual geoscientists. These submissions contended that Glen Roy did indeed fit well with SNH's revised NNR principles and criteria and that it is an international flagship geoheritage site that fully deserves the NNR accolade. It was considered by those campaigning to retain the NNR accolade, that de-declaring Glen Roy NNR was at odds with contemporary developments in geoconservation, particularly when international bodies such as IUCN and UNESCO have been highlighting the wider value of geoheritage (IUCN 2008, 2012; UNESCO, 2016), and with the formal adoption of Global Geoparks as part of the UNESCO International Geoscience and Geoparks Programme in November 2015, and endorsement of the new 'UNESCO Global Geopark' label. The campaign did recognise that Glen Roy and the wider Parallel Roads of Lochaber area will continue to be well protected under its SSSI designation, but they felt strongly that its wider value for public engagement and the opportunities it provides for people to experience and enjoy Scotland's geodiversity, and to be inspired about the natural landscape, had been overlooked in comparison with other NNRs with geoconservation interests, like for example Knockan Crag NNR (Scottish Natural Heritage, 2015). The campaign argued that Glen Roy deserves to be much better known in Scotland, and its 
location in Lochaber Geopark provides ideal opportunities for promotion through collaborative developments and innovative and visionary interpretation in ways that can enable the public to reconnect with nature and to rediscover a sense of wonder about the shaping of the landscape. For the campaign against de-declaring the NNR, the view was that loss of this accolade would diminish the perceived tourism value of Glen Roy. They have expressed a keenness to support the development of the NNR, if its NNR status is retained.

These interventions show how geoconservation has progressed since the late 1940s. While generations of geoscientists have demonstrated the outstanding scientific credentials and conservation value of the Parallel Roads of Glen Roy, local voices are now supporting the conservation of this remarkable and internationally important area.

In August 2015, following the representations, the Board of SNH agreed to delay de-declaring Glen Roy NNR for a further 18 to 24 months to enable engagement with interested parties to explore proposals for the future of the NNR. Lochaber Geopark Association has now been given the task of demonstrating through a development plan what could be done to promote the NNR to a wider audience and to make the visitor experience more enjoyable. Together, the local community (through the Geopark) and the scientific community (particularly through the QRA and RSGS) have a window of opportunity to demonstrate the value of the NNR and to explore with SNH how the accolade might be retained in the longer term.

\section{Conclusions}

Glen Roy is acclaimed for its outstanding value for Quaternary science, both for current research and its role in the history of the science, and for promoting geoheritage through geotourism activities within Lochaber Geopark. Glen Roy is an exemplar of the changing values attributed to geoheritage since Victorian times and earlier and their reflection in approaches to nature conservation more generally in Scotland and further afield. These approaches have progressed from a romantic view of the sublime character of natural wonders to a scientific one focused on protected areas, and then from the latter to a broader vision of sustainable management of the landscape in ways that deliver benefits for nature and people (Smout, 1993). The history of geoconservation of Glen Roy also exemplifies the wider post-war land-use conflicts and politics in the Highlands (Smout, 2000). In the face of contested values between different government departments, the persistent opposition to afforestation over nearly 20 years by the NC and concerted lobbying by the geoscience community ensured that most of Glen Roy within the original 1954 nature reserve proposal (although not the wider SSSI) remained un-afforested - a notable achievement for geoconservation.

Today-the notification of Glen Roy as an SSSI remains secure and safeguards the whole site. The threat of afforestation during the post-war years has also diminished, largely due to the better working relationships between government agencies. In the midst of the debate about the value of the scientific interest of Glen Roy in the mid-20th century, little attention was given to local voices and to local ownership of the wider, non-scientific geoheritage values of the area. This has been rectified more recently with the establishment of Lochaber Geopark and greater involvement of the local community. In line with the changing principles underlying NNRs in Scotland, the challenge of protecting and promoting the geoheritage of Glen Roy is now shared with Lochaber Geopark and linked to community engagement and sustainable development in rural areas. The Geopark and the scientific community, together with landowners and $\mathrm{SNH}$, have the potential to transform Glen Roy NNR and promote it in ways that the statutory bodies alone have been unable to do since its declaration in 1970. A key lesson is the need for open dialogue and partnership working to 
reach a pragmatic solution, involving the local the local community, land owners and managers, SNH, Lochaber Geopark and the scientific community.

The NNR designation is important to local people, the Geopark and the scientific community, who have collectively raised their concern that removing the NNR accolade from Glen Roy could be perceived as a loss of status for this internationally recognised geoconservation site.. However the removal of the immediate threat of de-declaration offers an opportunity, for engagement with all interested parties to explore proposals for the future of the NNR in the context of the broader scope of geoconservation outlined in section 2.2. Priority actions include preparation of a development plan, an interpretation plan and an assessment of the wider benefits provided by the NNR (although not all value can be quantified in financial terms). The scientific community also has an important ongoing role to provide the evidence base for the key themes and storylines for interpretation and outdoor education. Collectively and individually, they must actively engage, particularly to support the activities and development of the Geopark, and help to deliver the wider aims of Quaternary geoconservation (Brown et al., 2014). Much can be achieved if local people and the academic community combine their support. Among the possible ways forward, one solution could be to lease the NNR to Lochaber Geopark in the same way that the Swanscombe NNR is leased by Natural England to the local town council and forms part of their Heritage Park. Alternatively, the Community Empowerment (Scotland) Act 2015 may provide new opportunities for the local community to take on more involvement in managing Glen Roy for the local community and visitors to the SSSI and NNR. At a broader level, there is also a need for better integration of geoheritage in social, economic and nature conservation policies for rural areas and its recognition in national and local policy support measures, and by the business sector, including tourism, to enable sustainable funding for the geoparks in Scotland (Gordon, 2016). The current review of the NNR status could therefore provide the stimulus for innovation and an exciting new chapter in the conservation history of the Parallel Roads of Glen Roy.

\section{Acknowledgements}

We thank Christina Ross for preparing the diagrams. We are grateful for comments from numerous colleagues on earlier drafts of this paper, especially Clive Mitchell, and to Stewart Campbell and an anonymous reviewer for helpful comments that improved the manuscript.

\section{Note}

1 The terms 'Nature Reserve' and 'National Nature Reserve' are used in the context of the contemporary legislation. The National Parks and Access to the Countryside Act (1949) provided the legislative framework to enable the Nature Conservancy to designate Nature Reserves to be managed for the purpose of: (a) providing, under suitable conditions and control, special opportunities for the study of, and research into, matters relating to the fauna and flora of Great Britain and the physical conditions in which they live, and for the study of geological and physiographical features of special interest in the area, and/or (b) of preserving flora, fauna or geological or physiographical features of special interest in the area. Under the Wildlife and Countryside Act (1981), the Nature Conservancy Council was empowered, where it was satisfied that any land being managed as a Nature Reserve was of national importance, to declare that land to be a National Nature Reserve. Under subsequent legislation, this power has devolved to the statutory nature conservation bodies in England, Scotland and Wales. 


\section{References}

Agassiz, L., 1841. On glaciers, and the evidence of their having once existed in Scotland, Ireland and England. Proceedings of the Geological Society of London 3, 327-332.

Agassiz, L., 1842. The glacial theory and its recent progress. Edinburgh New Philosophical Journal 33, 217-283.

Ballantyne, C.K., 2012. Chronology of glaciation and deglaciation during the Loch Lomond (Younger Dryas) Stade in the Scottish Highlands: implications of recalibrated ${ }^{10} \mathrm{Be}$ exposure ages. Boreas 41, 513-526.

Bendle, J.M., Palmer, A.P., Carr, S.J., 2015. A comparison of micro-CT and thin section analysis of Lateglacial glaciolacustrine varves from Glen Roy, Scotland. Quaternary Science Reviews 114, 61-77.

Boston, C.M., Lukas, S., 2016. Evidence for restricted Loch Lomond Stadial plateau ice in Glen Turret and implications for the age of the Turret Fan. Proceedings of the Geologists' Association, http://dx.doi.org/10.1016/i.pgeola.2016.03.008.

Brilha, J., 2016. Inventory and quantitative assessment of geosites and geodiversity sites: a review. Geoheritage 8, 119-134.

Brown, E.J., Gordon, J.E., Burek, C.V., Campbell, S., Bridgland, D.R., 2014. Geoconservation and the Quaternary Research Association. In: Catt, J.A., Candy, I. (Eds.), The History of the Quaternary Research Association. Quaternary Research Association, London, pp. 405-431.

Burek, C.V., 2008. The role of the voluntary sector in the evolving geoconservation movement. In: Burek, C.V., Prosser, C.D. (Eds.), The History of Geoconservation. The Geological Society, London, Special Publications 300, pp. 61-89.

Burek, C.V., 2012. The role of LGAPs (Local Geodiversity Action Plans) and Welsh RIGS as local drivers for geoconservation within geotourism in Wales. Geoheritage 4, 45-63.

Burek, C.V., Prosser, C.D. (Eds.), 2008a. The History of Geoconservation. The Geological Society, London, Special Publications 300.

Burek, C.V., Prosser, C.D., 2008b. The history of geoconservation: an introduction. In: Burek, C.V., Prosser, C.D. (Eds.), The History of Geoconservation. The Geological Society, London, Special Publications 300, pp. 1-5.

Carcavilla, L., Durán, J.J., García-Cortés, Á., López-Martínez, J., 2009. Geological heritage and geoconservation in Spain: past, present, and future. Geoheritage 1, 75-91.

Canmore ID 108783 Glen Roy - Turret Bridge. Available at: http://canmore.org.uk/site/108783/glen-roy-turret-bridge (accessed 10 October 2016).

Coppock, J.T., 1960. A decade of post-war forestry in Great Britain. Economic Geography 36, 127-138.

Crofts, R., Gordon, J.E., 2015. Geoconservation in protected areas. In: Worboys, G.L., Lockwood, M., Kothari, A., Feary, S., Pulsford, I. (Eds.), Protected Area Governance and Management. ANU Press, Canberra, pp. 531-568.

Darwin, C., 1839. Observations on the Parallel Roads of Glen Roy and of other parts of Lochaber in Scotland, with an attempt to prove that they are of marine origin. Philosophical Transactions of the Royal Society of London 129, 39-81.

Darwin, F., 1887. The Life and Letters of Charles Darwin, Including an Autobiographical Chapter. Vol. 1. London, John Murray.

Darwin, F., Seward, A.C., 1903. More Letters of Charles Darwin. A Record of his Work in a Series of Hitherto Unpublished Letters. Vol. 2. John Murray, London. 
Devine, R.M., Palmer, A.P., 2016. A new varve thickness record from Alt Bhraic Achaidh Fan, middle Glen Roy, Lochaber: implications for understanding the Loch Lomond Stadial glaciolacustrine varve sedimentation trends. Proceedings of the Geologists' Association, http://dx.doi.org/10.1016/i.pgeola.2016.07.008.

Dowling, R.K., 2011. Geotourism's global growth. Geoheritage 3, 1-13.

Ellis, N., 2008. A history of the Geological Conservation Review. In: Burek, C.V., Prosser, C.D. (Eds.), The History of Geoconservation. The Geological Society, London, Special Publications 300, pp. 123-135.

Ellis, N., 2011. The Geological Conservation Review (GCR) in Great Britain - rationale and methods. Proceedings of the Geologists' Association 122, 353-362.

English Geodiversity Forum, 2014. Geodiversity Charter for England. Available at: http://www.englishgeodiversityforum.org/Downloads/Geodiversity\%20Charter\%20for\%2 OEngland.pdf (accessed 10 October 2016).

Erikstad, L., 2008. History of geoconservation in Europe. In: Burek, C.V., Prosser, C.D. (Eds.), The History of Geoconservation. The Geological Society, London, Special Publications 300, pp. 249-256.

Fabel, D., Small, D., Miguens-Rodriguez, M., Freeman, S.P., 2010. Cosmogenic nuclide exposure ages from the 'Parallel Roads' of Glen Roy, Scotland. Journal of Quaternary Science 25, 597-603.

Gordon, J.E., 1993. Glen Roy and the Parallel Roads of Lochaber. In: Gordon, J.E., Sutherland, D.G. (Eds.), Quaternary of Scotland. Geological Conservation Review Series No. 6. Chapman \& Hall, London, pp. 328-343.

Gordon, J.E., 1994. Conservation of geomorphology and Quaternary sites in Great Britain: an overview of site assessment. In: Stevens, C., Gordon, J.E., Green, C.P., Macklin, M.G. (Eds.), Conserving Our Landscape. Proceedings of the Conference Conserving Our Landscape: Evolving Landforms and Ice-Age Heritage, Crewe, UK, May 1992. English Nature, Peterborough, pp. 11-21.

Gordon, J.E., 1995. Louis Agassiz and the Scottish connection. Geology Today 11, 64-68.

Gordon, J.E., 2012. Rediscovering a sense of wonder: geoheritage, geotourism and cultural landscape experiences. Geoheritage 4, 65-77.

Gordon, J.E., 2016. Geoheritage case study: geotourism and geoparks in Scotland. In: Hose, T.A. (Ed.), Geoheritage and Geotourism: a European Perspective. Boydell \& Brewer Ltd, Martlesham, Suffolk, pp. 261-278.

Gordon, J.E., Baker, M., 2016. Appreciating geology and the physical landscape in Scotland: from tourism of awe to experiential re-engagement. In: Hose, T.A. (Ed.), Appreciating Physical Landscapes: Three Hundred Years of Geotourism. The Geological Society, London, Special Publications 417, pp. 25-40.

Gordon, J.E., Barron, H.F., 2012. Valuing geodiversity and geoconservation: developing a more strategic ecosystem approach. Scottish Geographical Journal 128, 278-297.

Gordon, J.E., Barron, H.F., 2013. Geodiversity and ecosystem services in Scotland. Scottish Journal of Geology 49, 41-58.

Gordon, J.E., McEwen, L.J., 1997. Glen Roy, Glen Spean and Glen Gloy, Highland. In: Gregory, K.J. (Ed.), Fluvial Geomorphology of Great Britain. Geological Conservation Review Series, No. 13. Chapman \& Hall, London, pp. 104-114.

Gordon, J.E., Barron, H.F., Hansom, J.D., Thomas, M.F., 2012. Engaging with geodiversity why it matters. Proceedings of the Geologists' Association 123, 1-6. 
Grant, E., 1988. Memoirs of a Highland Lady. Elizabeth Grant of Rothiemurchus. Edited by A. Tod. Canongate, Edinburgh.

Gray, M., 2013. Geodiversity: Valuing and Conserving Abiotic Nature. (2 $2^{\text {nd }}$ edition). Wiley Blackwell, Chichester.

Gray, M., Gordon, J.E., Brown, E.J., 2013. Geodiversity and the ecosystem approach: the contribution of geoscience in delivering integrated environmental management. Proceedings of the Geologists' Association 124, 659-673.

Henriques, M.H., dos Reis, R.P., Brilha, J., Mota, T., 2011. Geoconservation as an emerging geoscience. Geoheritage 3, 117-128.

Hose, T.A., 2000. European 'geotourism' - geological interpretation and geoconservation promotion for tourists. In: Barretino, D., Wimbledon, W.P., Gallego, E. (Eds.), Geological Heritage: Its Conservation and Management. Instituto Tecnológico Geominero de España, Madrid, pp. 127-146.

Hose, T.A., 2006. Geotourism and interpretation. In: Dowling, R., Newsome, D. (Eds.), Geotourism. Elsevier, London, pp. 221-241.

Hose, T.A., 2010. Volcanic geotourism in West Coast Scotland. In: Erfurt-Cooper, P., Cooper, M. (Eds.), Volcano and Geothermal Tourism: Sustainable Geo-resources for Leisure and Recreation. Earthscan, London, pp. 259-271.

Hose, T.A., 2012. 3G's for modern geotourism. Geoheritage 4, 7-24.

Houshold, I., Sharples, C., 2008. Geodiversity in the wilderness: a brief history of geoconservation in Tasmania. In: Burek, C.V., Prosser, C.D. (Eds.), The History of Geoconservation. The Geological Society, London, Special Publications 300, pp. 257272.

Hutton, J., 1788. Theory of the Earth; or an investigation of the laws observable in the composition, dissolution, and restoration of land upon the globe. Transactions of the Royal Society of Edinburgh 1, 209-304.

Inglis, H.R.G., 1934. The "Moving Patrol": A forgotten post-Culloden episode, 1747-1750. Scottish Geographical Magazine 50, 218-224.

IUCN, 2008. Resolutions and Recommendations adopted at the 4th IUCN World Conservation Congress. Resolution 4 040: Conservation of geodiversity and geological heritage. IUCN, Gland. Available at: https://portals.iucn.org/library/node/44190 (accessed 10 October 2016).

IUCN, 2012. Resolutions and Recommendations, World Conservation Congress, Jeju, Republic of Korea, 6-15 September 2012, WCC-2012-Res-048-EN Valuing and conserving geoheritage within the IUCN Programme 2013-2016. IUCN, Gland. Available at: https://portals.iucn.org/library/node/44015 (accessed 10 October 2016).

Jamieson, T.F., 1863. On the Parallel Roads of Glen Roy, and their place in the history of the glacial period. Quarterly Journal of the Geological Society of London 19, 235-259.

Jamieson, T.F., 1892. Supplementary remarks on Glen Roy. Quarterly Journal of the Geological Society of London 48, 5-28.

Kennedy, K., 1968. Parallel Roads of Glen Roy (letter). The Field, $29^{\text {th }}$ February 1968.

Larwood, J.G., Badman, T., McKeever, P.J., 2013. The progress and future of geoconservation at a global level. Proceedings of the Geologists' Association 124, 720 730.

Lauder, T.D., 1823. On the Parallel Roads of Lochaber. Transactions of the Royal Society of Edinburgh 9, 1-64. 
Macculloch, J., 1817. On the Parallel Roads of Glen Roy. Transactions of the Geological Society of London 4, 314-392.

Mackay, D., 1995. Scotland's Rural land Use Agencies: the History and Effectiveness in Scotland of the Forestry Commission, Nature Conservancy Council and Countryside Commission for Scotland. Scottish Cultural Press, Aberdeen.

Maclaren, C., 1840. Discovery of the former existence of glaciers in Scotland, especially in the Highlands, by Professor Agassiz. The Scotsman 25(2190), 3.

MacLeod, A., Palmer, A., Lowe, J., Rose, J., Bryant, C., Merritt, J., 2011. Timing of glacier response to Younger Dryas climatic cooling in Scotland. Global and Planetary Change 79, 264-274.

Mather, A.S., 1978. Patterns of afforestation in Britain since 1945. Geography 50, 157-166.

Mather, A.S., 2001. Forests of consumption: postproductivism, postmaterialism, and the postindustrial forest. Environment and Planning C 19, 249-268.

McKeever, P.J., Zouros, N., Patzak, M., 2010. The UNESCO Global Geoparks Network. European Geoparks Magazine 7, 10-13.

Miers, M., 2008. The Western Seaboard: an Illustrated Architectural Guide. RIAS Publishing, Edinburgh.

Milne Home, D., 1872. Scheme for the conservation of remarkable boulders in Scotland, and for the indication of their position on maps. Proceedings of the Royal Society of Edinburgh 7, 475-488.

Palmer, A.P., Lowe, J.J., Rose, J. (Eds.), 2008. The Quaternary of Glen Roy and Vicinity. Field Guide. Quaternary Research Association, London.

Palmer, A.P., Rose, J., Lowe, J.J., MacLeod, A., 2010. Annually resolved events of Younger Dryas glaciation in Lochaber (Glen Roy and Glen Spean), Western Scottish Highlands. Journal of Quaternary Science 25, 581-596.

Palmer, A.P., Rose, J., Rasmussen, S.O., 2012. Evidence for phase-locked changes in climate between Scotland and Greenland during GS-1 (Younger Dryas) using micromorphology of glaciolacustrine varves from Glen Roy. Quaternary Science Reviews 36, 114-123.

Peacock, J.D., 1989. Survey of Quaternary landforms and deposits of Glen Roy, Glen Gloy and Glen Spean, Lochaber District, and recommendations for conservation. CSD Report, No. 923. Nature Conservancy Council, Peterborough.

Peacock, J.D., 2009.The QRA 2008 Field Guide to the Quaternary of Glen Roy and vicinity: a discussion. Quaternary Newsletter 118, 1-7.

Peacock, J.D., Cornish, R. (Eds.), 1989. Glen Roy Area. Field Guide. Quaternary Research Association, Cambridge.

Peacock, J.D., Gordon, J.E., May, F., 2004. Glen Roy. A Landscape Fashioned by Geology. Scottish Natural Heritage, Battleby.

Pennant, T., 1771. A Tour in Scotland 1769. John Monk, Chester.

Prosser, C.D., 2012. William Archibald Macfadyen (1893-1985): the 'father of geoconservation'? Proceedings of the Geologists' Association 123, 182-188.

Prosser, C.D., 2013a. Our rich and varied geoconservation portfolio: the foundation for the future. Proceedings of the Geologists' Association 124, 568-580.

Prosser, C.D., 2013b. Planning for geoconservation in the 1940s: an exploration of the aspirations that shaped the first national geoconservation legislation. Proceedings of the Geologists' Association 124, 536-546. 
Prosser, C.D., Larwood, J.G., 2008. Conservation at the cutting edge: the history of geoconservation on the Wren's Nest National Nature Reserve, Dudley, England. The Geological Society, London, Special Publications 300, pp. 217-235.

Prosser, C.D., Bridgland, D.R., Brown, E.J., Larwood, J.G., 2011. Geoconservation for science and society: challenges and opportunities. Proceedings of the Geologists' Association 122, 337-342.

Prosser, C.D., Brown, E.J., Larwood, J.G., Bridgland, D.R., 2013. Geoconservation for science and society - an agenda for the future. Proceedings of the Geologists' Association 124, 561-567.

Reynard, E., 2009. Geomorphosites: definitions and characteristics. In: Reynard, E., Coratza, P., Regolini-Bissig, G. (Eds.), Geomorphosites. Verlag Dr. Friedrich Pfeil, Munich, pp. 9-20.

dos Reis, R.P., Henriques, M.H., 2009. Approaching an integrated qualification and evaluation system for geological heritage. Geoheritage 1, 1-10.

Ross, T., 1796. Parish of Kilmanivaig. In: Sinclair, Sir J. (Ed.), The Statistical Account of Scotland, Vol. 17. William Creech, Edinburgh, pp. 543-550.

Rudwick, M.J.S., 1962. Hutton and Werner compared: George Greenough's geological tour of Scotland in 1805. The British Journal for the History of Science 1,117-135.

Rudwick, M.J.S., 1974. Darwin and Glen Roy: a "great failure" in scientific method? Studies in the History and Philosophy of Science 5, 97-185.

Rudwick, M.J.S., 2009. The Parallel Roads of Glen Roy: in the Footsteps of Charles Darwin. A Field Guide. The Geological Society of London, History of Geology Group. Available at: https://www.darwinproject.ac.uk/sites/default/files/Rudwick Glen-Roy-fieldguide DCP.pdf (accessed 10 October 2016).

Rudwick, M.J.S., 2016. The origin of the Parallel Roads of Glen Roy: a review of 19th Century research. Proceedings of the Geologists' Association, http://dx.doi.org/10.1016/..pgeola.2016.04.001.

Scottish Geodiversity Forum, 2013. Scotland's Geodiversity Charter. Available at: http://scottishgeodiversityforum.org/charter/ (accessed 10 October 2016).

Scottish Natural Heritage, 2011. Sites of Special Scientific Interest. Scottish Natural Heritage, Battleby.

Scottish Natural Heritage, 2015. Scotland's National Nature Reserves: Knockan Crag. Available at: http://www.nnr-scotland.org.uk/knockan-crag/ (accessed 10 October 2016).

Sharples, C., 2002. Concepts and Principles of Geoconservation. Tasmanian Parks and Wildlife Service, Hobart. Available at: http://dpipwe.tas.gov.au/Documents/geoconservation.pdf(accessed 10 October 2016)

Sharples, C., 2003. A review of the geoconservation values of the Tasmanian Wilderness World Heritage Area. Nature Conservation Report 03/06, Department of Primary Industries, Water and Environment, Tasmania. Available at: http://dpipwe.tas.gov.au/conservation/publications-forms-and-permits/publications/areview-of-the-geoconservation-values-of-the-twwha (accessed 10 October 2016).

Sissons, J.B., 1977. Glen Roy National Nature Reserve: The Parallel Roads of Glen Roy. Nature Conservancy Council, London.

Sissons, J.B., 1978. The parallel roads of Glen Roy and adjacent glens, Scotland. Boreas 7, 229-244.

Sissons, J.B., 1979a. The later lakes and associated fluvial terraces of Glen Roy, Glen Spean and vicinity. Transactions of the Institute of British Geographers 4, 12-29. 
Sissons, J.B., 1979b. The limit of the Loch Lomond Advance in Glen Roy and vicinity. Scottish Journal of Geology 15, 31-42.

Sissons, J.B., 1979c. Catastrophic lake drainage in Glen Spean and the Great Glen, Scotland. Journal of the Geological Society of London 136, 215-24.

Sissons, J.B., 1981a. Lateglacial marine erosion and a jökulhlaup deposit in the Beauly Firth. Scottish Journal of Geology 17, 7-19.

Sissons, J.B., 1981b. Ice-dammed lakes in Glen Roy and vicinity: a summary. In: Neale, J., Flenley, J. (Eds.), The Quaternary in Britain. Pergamon Press, Oxford, pp. 174-183.

Sissons, J.B. 2016a. The varve-related ice-dammed lake events in Glen Roy and vicinity: a new interpretation. Proceedings of the Geologists' Association, http://dx.doi.org/10.1016/i.pgeola.2014.12.007.

Sissons, J.B. 2016b. The lateglacial lakes of Glens Roy, Spean and vicinity (Lochaber district, Scottish Highlands). Proceedings of the Geologists' Association, http://dx.doi.org/10.1016/j.pgeola.2015.12.004.

Sissons, J.B., Cornish, R., 1982a. Rapid localized glacio-isostatic uplift at Glen Roy, Scotland. Nature 297, 213-214.

Sissons, J.B., Cornish, R., 1982b. Differential glacio-isostatic uplift of crustal blocks at Glen Roy, Scotland. Quaternary Research 18, 268-288.

Sissons, J.B., Cornish, R., 1983. Fluvial landforms associated with ice-dammed lake drainage in upper Glen Roy, Scotland. Proceedings of the Geologists' Association 94, 45-52.

Smout, T.C., 1993. The Highlands and the roots of green consciousness, 1750-1990. Scottish Natural Heritage Occasional Paper No. 1. Scottish Natural Heritage, Edinburgh.

Smout, T.C., 2000. Nature Contested. Environmental History in Scotland and Northern England Since 1600. Edinburgh University Press, Edinburgh.

Stace, H., Larwood, J.G., 2006. Natural Foundations: Geodiversity for People, Places and Nature. English Nature, Peterborough.

Stewart, I.S., Nield, T., 2013. Earth stories: context and narrative in the communication of popular geosciences. Proceedings of the Geologists' Association 124, 699-712.

Strauss, S., 2007. The impact of the artistic. Interpretation Journal 12(3), 12-14.

Thomas B.A., Warren L.M., 2008. Geological conservation in the nineteenth and early twentieth centuries. In: Burek, C.V., Prosser, C.D. (Eds.), The History of Geoconservation. The Geological Society, London, Special Publications 300, pp. 17-30.

Tronkov, D., Sinnyovsky, D., 2012. Belogradchik rocks, Bulgaria: geological setting, genesis and geoconservation value. Geoheritage 4, 153-164.

UNESCO, 2016. UNESCO Global Geoparks. UNESCO, Paris. Available at: http://unesdoc.unesco.org/images/0024/002436/243650e.pdf (accessed 10 October 2016).

Wang, L., Tian, M., Wang, L., 2015. Geodiversity, geoconservation and geotourism in Hong Kong Global Geopark of China. Proceedings of the Geologists' Association 126, 426437.

Whiteley, M.J., Browne, M.A., 2013. Local geoconservation groups - past achievements and future challenges. Proceedings of the Geologists' Association 124, 674-680. 